\title{
RECENZE KNIHY: \\ Bartoš, A., Raisová, M. (2015). Testy a dotazníky pro vyšetřování kognitivních funkcí, nálady a soběstačnosti. Praha: Mladá fronta.
}

\author{
TOMÁš URBÁNEK ${ }^{1}$, JAROSLAV GOTTFRIED ${ }^{2}$ \\ ${ }_{1}^{1}$ Psychologický ústav AV ČR, v.v.i., ${ }^{2}$ Katedra psychologie FSS MU
}

\begin{abstract}
Abstrakt: Text je recenzí knihy Testy a dotazníky pro vyšetřování kognitivních funkcí, nálady a soběstačnosti od Aleše Bartoše a Miloslavy Raisové, vydané Mladou frontou. Podobné publikace jsou potřebné a potenciálně užitečné jak pro praktiky, tak výzkumníky. Recenzovaná kniha je ale v mnoha ohledech problematická, předevš́m z psychometrického hlediska, které považujeme pro podobný typ publikací za klíčové, a sami autoři tvrdí, že je $v$ knize akcentují. Podle našeho názoru úroveň psychometrických poznatků v této knize odpovídá začátku 90. let minulého století, což v současnosti nelze akceptovat.
\end{abstract}

Publikace věnované psychologickým diagnostickým metodám jsou potřebné a mohou být užitečné jak pro praktiky, tak pro výzkumníky. Jednou takovou publikací je i kniha Testy a dotazníky pro vyšetřování kognitivních funkcí, nálady a soběstačnosti od A. Bartoše a M. Raisové, vydaná Mladou frontou. Už v úvodu musíme upozornit na to, že je v mnoha ohledech problematická, v některých ohledech dokonce vzbuzuje rozpaky, a to především z psychometrického hlediska, které při hodnocení podobných knih považujeme za klíčové. Hodnocení začneme od celkového dojmu z knihy a budeme postupovat dále ke konkrétnímu obsahu.

Recenzovaná kniha je vázána v kroužkové vazbě, barevná, podporovaná několika sponzory a projekty a obsahuje řadu reklam na jiné publikace a farmaceutické př́pravky, které poněkud narušují plynulost četby. Obsahuje třináct kapitol, každou s vlastním seznamem použité literatury (domníváme se, že kniha dvou autorů by měla mít společný seznam citované literatury, anebo aspoň jmenný rejstřík), seznam dalších literárních zdrojů, seznam zkratek a vysvětlivek a (věcný) rejstř́ík. Autory jsou klinický neurolog a klinická psycholožka se zaměřením na neuropsychologii, u každé z kapitol je explicitně uvedeno, kdo je autorem, jako recenzentky jsou uvedeny psychiatryně a klinická psycholožka.

\footnotetext{
1 Psychologický ústav Akademie věd, v.v.i., Veveř́ 967/97, 60200 Brno

2 Katedra psychologie, Fakulta sociálních studií Masarykovy univerzity, Joštova 10, 60200 Brno
} 
Nejprve uvedeme několik suchých kvantitativních údajů, které jsou nicméně velmi informativní. Kniha je vytištěna na 150 stranách, z nichž více než deset obsahuje celostránkové reklamy, dalších cca deset stran obsahuje rejstříky, seznam literatury, seznam zkratek a vysvětlivky, údaje o autorech, osmiřádkový závěr ve formě dopisu autorů čtenářum a osmiřádkové souhrny v češtině a angličtině. Zbylých cca 120 stran obsahuje údaje o více než dvaceti testech a dotaznících, na informace o každém testu tedy zbývá v průměru méně než deset stran. To by ještě nemuselo znamenat velký problém, kdyby zmíněné stránky přinášely důležité informace. Na více než deseti stranách jsou ale přetištěny celé záznamové archy metod nebo př́klady odpovědí, které by mohly být užitečné jako doplňkové informace, ale v této knize zabírají místo informacím, které až bolestivě chybějí.

Kniha na první pohled působí dojmem, že autoři možná věnovali čas psaní a př́ípravě tabulek a obrazového materiálu, ale nikoli už další redakční práci. Tento dojem je umocněn poté, když se začteme do úvodních stran - vyskytují se na nich zvláštní formulace, jako „... který jsme uskutečnili při řešení především čtyřletého grantu“ (s. 9) nebo „... českých seniorů bez kognitivní poruchy i včetně ní“ (tamtéž), popř. matematické nesmysly jako „negativní pravděpodobnost Alzheimerovy nemoci“ (s. 10). Abychom však neulpívali pouze na povrchních dojmech a výčtu několika stylistických neobratností, posuneme se k samotnému obsahu.

Kniha je uvozena poněkud nesrozumitelným mottem (Zdání klame, ale testem či dotazníkem vadne), sympatickým věnováním spisovateli Pratchettovi, který zemřel na Alzheimerovu nemoc, jeho fanouškům a profesoru Oskaru Fisherovi, který popsal Alzheimerovu nemoc jako první, a poděkováním řadě spolupracovníků. Úvodní kapitola, která má pouze dvě strany, se jmenuje „Psychometrický rébus z ordinace na úvod“, takže čtenář-psychometrik musí nutně zbystřit pozornost. Napsat knihu o psychometrických přístupech v neuropsychologické diagnostice zábavným a hravým způsobem by bylo velmi užitečným počinem.

Ve zmíněné úvodní kapitole autoři prezentují krátkou charakteristiku vyšetřovaného pacienta a jeho výsledky ve větším počtu testů, pravděpodobně aby čtenáře motivovali zajímat se o význam a interpretaci takových výsledků. Autoři zde poskytují čtenáři opravdu velice kusé informace - např. u jedné z dotazníkových metod je uveden výsledek: „2 body, tj. 93 \%“ (s. 11). Čtenář musí být těmito informacemi zmaten - čeho se údaj týká? Jde o celkovou procentuální úspěšnost či o percentil? Uvedené výsledky mají skutečně charakter rébusu, protože jsou zde uvedeny dříve nevysvětlené zkratky a údaje mají spíše charakter pracovních poznámek, jako by celá kniha měla být jednou podrobnou kazuistikou. Rozpaky v nás proto vyvolává opakující se tvrzení autorů, že kniha má čtenáře naučit „číst mezi řádky“ - je to snad důvod, proč v knize chybí klíčové informace? 
Nebudeme sice podrobně hodnotit neuropsychologické aspekty knihy; není to naše specializace, ale $\mathrm{v}$ (dvoustránkové) kapitole 3 , ve které se autoři věnují kódování Alzheimerovy nemoci a dalších nemocí s kognitivními poruchami a symptomy v MKN-10, je obsažen jen stručný úvod a pak už jen tabulky s kódy a názvy. Domníváme se, že pro odborníka nebo budoucího odborníka (klinického psychologa) jsou tyto informace př́liš stručné a běžnému čtenáři (studentovi, sociálnímu pracovníkovi apod.) také mnoho užitečného nepřinesou. Tabulka 3.1 (s. 16-17) obsahuje celou řadu různých kódů diagnóz, se kterými se však v textu nepracuje. Další relevantní kapitola, věnovaná kognitivním funkcím a jejich diagnostice, má pouhých pět stran.

Už v předmluvě autoři avizují, že by chtěli čtenáře seznámit s principy psychometrie a testování, představit souhrnný přehled kognitivních testů a dotazníků pro zjišt'ování nálady a soběstačnosti a prezentovat normy a hranice (zřejmě hraniční skóry) pro Alzheimerovu nemoc u jednotlivých testů. Domníváme se, že všechny tyto cíle se jim bohužel splnit nepodařilo. Psychometrická část knihy, která nás zajímá primárně, je značně stručná, a tudíž neúplná, a přestože čtenáře chvályhodně seznamuje s pojmy sensitivita a specificita a od nich odvozenými indexy, v podstatě úplně opomíjí klíčové psychometrické pojmy, jakými jsou validita a reliabilita, na ni navazující problematiku standardní chyby měření, a otázky tvorby norem a hodnocení jejich kvality. To jsou tzv. standardy, jejichž vědecká a empirická reflexe zakládá právo na označení standardizovaných metod.

Vysvětlení výše zmíněných pojmů a jejich vzájemných vztahů pak kriticky chybí v případě, kdy bychom chtěli u jednotlivých prezentovaných testů vysvětlit např. to, jaké aspekty poruchy kognitivních funkcí zjišt'ují (validita) a s jakou mírou přesnosti jsou tyto hodnoty zjišt'ovány (reliabilita), tzn., jaké pásmo např. na škále percentilů je třeba vzít v úvahu při interpretaci výsledků. Tyto pojmy ale vysvětleny nejsou a v prezentacích testů se s nimi nepracuje. Místo toho jsou skóry brány vážně jako bodové hodnoty, což je z psychometrického hlediska přinejmenším naivní.

Přes značně obecný název je kniha zaměřena hlavně na metody diagnostiky Alzheimerovy nemoci a mírné kognitivní poruchy a dalším aspektům diagnostiky kognitivních poruch se věnuje jen okrajově. V předmluvě je zmiňován čtyřletý grantový projekt, ze kterého pocházejí data, na nichž jsou zřejmě založeny výsledky analýz, chybí ale podrobnosti např. o metodologii sběru dat a podrobnosti o charakteristikách výběrového souboru. Důležitou otázkou je také způsob diagnostikování Alzheimerovy nemoci nebo mírné kognitivní poruchy - bylo prováděno „naslepo“, tzn., že výzkumníci administrující testy nevěděli, jestli vyšetřují osobu s diagnózou AN nebo bez ní? Pokud ne, mohlo by to vést k nadhodnocení sensitivit a specificit použitých testů. Tato otázka není v textu knihy uspokojivě zodpovězena.

V případě analýz ROC je vždy klíčová otázka, jaké kritérium bylo použito ke stanovení diagnózy. Vzhledem $\mathrm{k}$ tomu, že prezentované testy zjišt'ují různé psychické funkce a charakteristiky, každá taková analýza by měla být založena na vlastním kritériu, kterému se v literatuře říká „zlatý standard“. Údaje o těchto kritériích ale v knize nejsou 
uvedeny, takže nelze posoudit adekvátnost hodnot sensitivity a specificity uvedených v tabulkách v knize. Vzniká podezření, že všechny osoby z výběrového souboru byly posouzeny na základě stejného kritéria ( $v$ roli „podezřelého“ je MMSE), což je značně diskutabilní postup, jehož problematičnost je navíc zvýrazněna faktem, že kritérium neznáme.

K výše uvedenému zásadnímu komentáři ke knize můžeme přidat ještě několik detailnějších poznámek, týkajících se dílčích převážně psychometrických témat.

Na s. 21 (kap. 5) může čtenář ze způsobu argumentace nabýt dojmu, že percentil je lepším ukazatelem výsledků vyšetřeného pacienta, protože jeho použití není podmíněno normálním rozložením. To je sice do značné míry pravda, ale současně je potřeba upozornit na to, že v případě výskytu nenormálního rozložení je při interpretaci percentilů nutné tvar rozložení znát a brát ho do úvahy. Mechanické spojování určitých hodnot percentilů s charakteristikami výkonu tedy obecně není možné.

Např. na s. 23 je uvedeno „V literatuře lze najít zdůvodnění...“ týkající se interpretace hodnot věrohodnostního poměru. Domníváme se, že takové tvrzení je nutné doložit citací nebo citacemi. Podobných autoritativních tvrzení bez citační opory je v knize více.

Jak již bylo výše stručně zmíněno, celá jedna kapitola (pátá) se zabývá problematikou určování hraničních (cut-off) skórů pomocí průměrů a směrodatných odchylek, percentilů a analýzy ROC využívající sensitivitu a specificitu a z nich odvozené indexy jistoty, věrohodnostního poměru a diagnostického poměru šancí. Tato kapitola sice poskytuje řadu užitečných informací, ale zásadní informace v ní chybí (a nejsou uvedeny ani jinde v knize) - především informace o tom, že aby vůbec mělo smysl výsledky testování interpretovat, musí být předloženy důkazy o validitě testu, tzn. to, že test skutečně zjišt'uje to, co zjišt'ovat má. Přestože autoři avizují, že kniha čtenářùm vysvětlí základní psychometrické pojmy, tento klíčový pojem se v knize snad vůbec nevyskytuje. Další klíčový pojem, který v knize schází, je pojem reliability - tzn. v podstatě přesnosti měření. Uvažovat o hraničních skórech bez znalosti intervalů spolehlivosti vypočítaných na základě standardní chyby měření odvozené z reliability znamená př́lišné zjednodušení procesu interpretace testových skórů.

Dále bychom se chtěli vrátit k tzv. jistotě (tvořené součtem sensitivity a specificity), která by mohla mít omezený smysl snad jen při porovnávání velmi podobně zaměřených testů a v případě, že sensitivita a specificita pro nás mají stejnou důležitost. I pak je podle našeho názoru metoda sčítání sensitivity a specificity př́liš zjednodušující (nehledě na to, že matematicky postrádá smysl). Chybí též důležité upozornění, že není vždy nejlepší použít test s největší mírou jistoty, nejvyšším poměrem šancí, nebo nejlepšími výsledky ROC, protože vždy záleží na zamýšleném použití testu, prevalenci nemoci $\mathrm{v}$ populaci a důsledcích chybné diagnózy (např. screeningu, kde chceme především vysokou senzitivitu, oproti celoplošnému testování velkého množství lidí, kde 
chceme spíše větší specificitu, abychom nedosáhli příliš vysokého počtu falešně pozitivních př́ípadů).

Abychom nebyli pouze ve svém hodnocení pouze negativní, měli bychom zmínit i několik pozitivních aspektů, které jsme v knize našli. Např. vysvětlení, jak pracovat s klientem vambulanci, považujeme za př́nosné. Rovněž tabulky na s. 120-122, přestože mají charakter výpisků nebo poznámek, jsou přehledné a představují pro čtenáře dobré prvotní vodítko kvolbě metody vzávislosti na testované kognitivní funkci.

Autorům se podle našeho názoru podařilo splnit jeden ze tří cílů stanovených v úvodu knihy - představit souhrn nejčastěji používaných psychodiagnostických metod k vyšetřování Alzheimerovy nemoci. Jejich druhý cíl, spočívající v prezentování norem pro seniorskou populaci byl naplněn pouze částečně, jelikož normy nebyly poskytnuty pro všechny metody a vzhledem k chybějícím informacím a psychometrickým nejasnostem jsou možnosti jejich adekvátního užití v praxi v současné podobě značně omezené. Třetí cíl - seznámit čtenáře s principy psychometrie a testování, se naplnit nepodařilo. Kniha s výjimkou cut-off skórů a vágního hodnocení sensitivity a specificity psychometrickým otázkám vůbec nevěnuje. Kniha proto může pro některé čtenáře představovat užitečný materiál $\mathrm{k}$ úvodnímu seznámení se s množstvím psychodiagnostických metod, jež je k dispozici pro zjišt’ování přítomnosti Alzheimerovy nemoci. Nicméně psychometrickým základům testování, kritickému hodnocení kvalit diagnostických metod, ani korektní interpretaci jejich výsledků se čtenář díky této knize nenaučí.

Když celkově shrneme naše hodnocení knihy, musíme bohužel konstatovat, že jde o pokračování neblahé české (resp. kdysi československé) tradice naivního psychometrického kutilství typického pro 80. a raná 90. léta, kdy čeští autoři metod neměli potřebnou kombinaci znalostí, vybavení a zkušeností s psychometrickými metodami, aby mohli podnikat plnohodnotné pokusy o konstrukci a adaptaci testových metod. Jejím důsledkem je rezignace části odborníků z oblasti aplikované praxe na prosazování plnohodnotných postupů a místo toho používání jakési „dojmologické“, „pseudoumělecké“ kvazilogiky, která není ve prospěch rozvíjení na důkazech založené praxe. Dnes už ale potřebnou kombinací znalostí, vybavení a zkušeností v psychologických odborných kruzích disponujeme, a proto počiny, jakými je recenzovaná kniha, nelze hodnotit pozitivně. 